DOI: $10.1007 / \mathrm{s} 10694-017-0677-8$

\title{
Obifuary
}

\section{In Memoriam: Professor Margaret Law MBE BSc CEng FlFireE FSFPE}

\author{
Peter Johnson, Arup, Melbourne, Australia
}

Barbara Lane*, Arup, London, UK

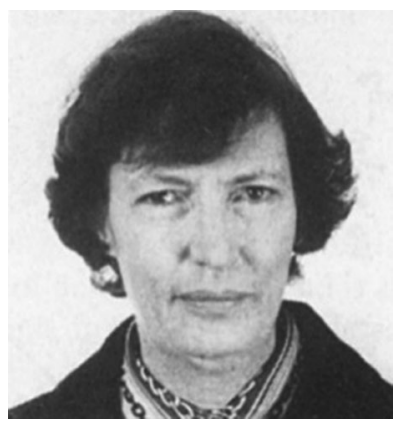

Margaret Law, an international pioneer and a major influence in our professional world of fire science and fire safety engineering, has died peacefully at her home in London, on 27th August 2017.

Margaret was born in London and graduated in physics and mathematics from the University of London (BSc). She joined the Fire Research Station in the UK in 1952, and over 20 years established herself as one of the world's leading fire scientists, carrying out research into many aspects of fire behaviour and its effects on building materials and structures. She also became involved in the application of these research results in Building Regulations, Codes of Practice, and design guides. Her particular research interests included ignition and fire dynamics, heat radiation from fires and requirements for building separation, as well as structural fire behaviour.

Margaret next spent a few years in the Directorate of Research Requirements at the Department of the Environment in the UK, assessing research priorities in the field of building and construction.

The application of research to solve practical problems was of particular interest to her and so in 1974 she joined the Ove Arup Partnership to act as an adviser on fire engineering for projects being designed within the firm. She went on to create innovative fire safety solutions on major projects such as the Pompidou Centre

\footnotetext{
* Correspondence should be addressed to: Barbara Lane, E-mail: Barbara.Lane@arup.com
} 
in Paris, the Lloyds Building and Stansted Airport Terminal Building in the UK and Kansai International Airport in Japan. She was particularly renowned for her work on structural steelwork in fire, with codified methods still relied on today in the USA, UK and Europe.

Margaret was concerned with all aspects of fire safety, particularly in those buildings for which the standard rules and requirements of regulations were not directly applicable. She always published and explained her work, such that others could understand, interrogate, and implement it. She was a visiting researcher at the Science University of Tokyo in 1987 and was made Visiting Professor at the University of Greenwich in 1997. She was actively involved in National and International Committees concerned with fire safety throughout her career, getting fire safety engineering principles accepted within codes/standards and the regulatory framework. She gave much time to the work of the professional institutions. In the UK, she was instrumental in developments that culminated in fire engineers achieving chartered status through the Institution of Fire Engineers. She received a number of national and international awards, including an MBE in 1993 for her services to fire safety, and the Arthur B Guise Medal from the Society of Fire Protection Engineers in 1994.

At the end of 1990 Margaret Law retired and became a Consultant to the Ove Arup Partnership. Her book of papers "Some selected papers by Margaret Law: engineering fire safety" was produced to honour her achievements when she finished this Consultant role in 2002. The best and most influential 29 papers in the book are testament to Margaret's high standards, commitment to fundamental scientific understanding, her technical rigour, and her ability to translate fundamental principles into practical building design solutions.

Margaret must have surely rejoiced in 1985 when her fire engineering fraternity colleagues such as Philip Thomas formed the International Association of Fire Safety Science (IAFSS). The aim was to stimulate research into fire science globally, and provide the proper fire scientific basis for fire engineering design.

Margaret gave one of her most significant presentations with a paper entitled "Translation of Research into Practice - Building Design" at the very first International Symposium on Fire Safety Science held at NIST in Gaithersburg in the USA in October 1985. This was at the heart of her message about the importance of bringing fire research into the everyday practice of the design fire engineer.

Margaret continued to attend IAFSS Symposia and, with her Arup colleague Paula Beever, they gave a wonderful presentation of their paper "Magic Numbers and Golden Rules" at the Fourth International Symposium of Fire Safety Science in Ottawa in 1994. In Melbourne at the Fifth International Symposium on Fire Safety Science in Melbourne in March 1997 she gave paper entitled "A review of the Formulae for t-equivalent". All the while Margaret was driving at moving fire safety design away from prescriptive rules into a robust field of engineering.

Other significant papers in the book which showed her passion and approach to the fire engineering profession include "Using Science and Hunting Facts", the title of her Arthur B. Guise Medal Lecture to the SFPE in London in 1994, and the "Origin of the 5MW Fire" give at a fire engineering conference in 1995. 
It is difficult to communicate just how influential Margaret's scientific work was, and continues to be; just as her fire safety engineering work during her time at Arup was and continues to be so influential.

She believed profoundly in what she termed measurement and as she herself said in her 1990 Paper-What is a Fire Engineer? "Measurement and quantification are fundamental to any proper engineering design. It is sad so many people are reluctant to measure things: presumably that might cast doubts on what they know to be right".

This belief drove her work which was always founded on quantified scientific criteria, and always rigorously derived.

Margaret expected fire safety engineers to be "tough enough to stand up to a good deal of questioning" and in turn "to be able to push other people in the same way: justify what you are saying if you expect to be taken seriously". For some therefore she was terrifying to justify a theory to - she had a fearsome reputation, and rightly so. And this is also exactly why she was so deeply respected and so greatly admired. She was a devoted, kind and patient teacher to those of us who were lucky enough to work with her, and all colleagues at Arup and others have greatly enjoyed sharing the stories and memories of Margaret through her great career.

There are two great monuments to Margaret's lifetime achievement. The first is the body of her published work; the second is the worldwide consultancy practice of Arup Fire, now some 220 strong, and still growing. Margaret was a private and humble person. We don't know if she ever understood her influence, her global reputation, and the esteem with which she was held by so many.

Arup is looking to develop some lasting technical event, award, scholarship or other means to remember and celebrate the life of Margaret Law. 